\title{
The Impact of Firm-Specific and Macroeconomic Factors on Financial Distress Risk: A Case Study from Turkey
}

\author{
Isil Erem Ceylan \\ Faculty of Economics and Administrative Sciences, Department of Business Administration, Usak University, Usak, 64000, Turkey
}

Received March 31, 2021; Revised June 8, 2021; Accepted June 28, 2021

\begin{abstract}
Cite This Paper in the following Citation Styles
(a): [1] Isil Erem Ceylan, "The Impact of Firm-Specific and Macroeconomic Factors on Financial Distress Risk: A Case Study from Turkey," Universal Journal of Accounting and Finance, Vol. 9, No. 3, pp. 506 - 517, 2021. DOI: 10.13189/ujaf.2021.090325.
\end{abstract}

(b): Isil Erem Ceylan (2021). The Impact of Firm-Specific and Macroeconomic Factors on Financial Distress Risk: A Case Study from Turkey. Universal Journal of Accounting and Finance, 9(3), 506 - 517. DOI: 10.13189/ujaf.2021.090325.

Copyright $\bigcirc 2021$ by authors, all rights reserved. Authors agree that this article remains permanently open access under the terms of the Creative Commons Attribution License 4.0 International License

\begin{abstract}
The purpose of this study is to examine the impact of both firm-specific and macroeconomic factors on the financial distress risk of the firms listed in the Borsa Istanbul Small and Medium Enterprises (SMEs) Industrial Index over the period from 2010 to 2019. Generalized Method of Moments (GMM) estimator is used to determine the potential impact of firm-specific and macroeconomic factors on financial distress risk. The dependent variable used in the study is financial distress risk measured by Springate S score. This study considers the independent variables by incorporating both firm-specific (current ratio, quick ratio, asset turnover, debt ratio, financial leverage, and return on assets) and macroeconomic factors (economic growth, exchange rate, and inflation rate) in the analysis of financial distress risk. The empirical results show that the current ratio, quick ratio, asset turnover, debt ratio, financial leverage, and return on assets have a statistically significant positive impact on financial distress risk. On the contrary, the findings document a negative association between percentage change in the consumer price index and financial distress risk. To the best of the author's knowledge, this is one of the several studies seeking to identify the determinants of financial distress risk for Turkish SMEs by considering both firm-specific ratios and macroeconomic indicators with panel data analysis (generalized method of moments). This study may be extendable to be used by SMEs and may provide a remarkable resource for them. Also, the obtained results equate numerous practical implications nominately for the executives of SMEs as mentioned in the conclusion part of the study.
\end{abstract}

Keywords Financial Distress Risk, Firm-Specific
Factors, Macroeconomic Factors, Financial Ratios, Springate S Score Model, Small and Medium Enterprises

\section{Introduction}

Firms sometimes fall into a difficult situation and face the danger of not being able to survive, especially due to the problems arising from managerial and financial reasons, the economic crises or political problems in the country in which they operate, and global crises in the world economy. The fact is that they have to operate in an environment dominated by risk and uncertainty may face some difficulties. These problems may increase over time and cause firms to fail. Many situations can be expressed as financial distress such as late payment of its debts (interest and principal installments of short and long-term liabilities, payment after the counterparty's balance sheet becomes suspicious, etc.), losing its credibility, and bankruptcy. Financial distress is a result that may happen to all firms, without distinction between small- and large-scale firms or developed country and developing country firms [8]. This situation may emerge differently according to the scale of the firms. For instance, the effect of macroeconomic variables on the functioning of the real sector may vary depending on the firm scale. Large firms have the power to affect the course of economic variables and to minimize the possible negative effects of economic variables by using market power. However, SME-sized firms have to consider the changes in the macroeconomic environment as data and adjust their 
activities according to these data [21].

SMEs play an essential role in the sense of their contribution to employment and production, their flexibility to rapidly adapt to changing market conditions, their ability to complete large firms, their positive impact on interregional balanced growth and environmental protection, and a fairer distribution of income. At this point, it is vital that SMEs may adapt to the changes in the macroeconomic environment by managing them in an effective, planned and rational manner, as they are an important element of economic growth and development [38]. As can be seen, determining how firm-specific or macroeconomic variables may affect the financial distress of firms is of great importance by all parties such as managers, consultants, auditors, financial analysts, lenders, etc. For example, if the firm managers or consultants aim to identify the strategies that will move the firm forward, they should efficiently analyze the relationship between firms-specific or macroeconomic variables and the level of firm development. In addition, creditors may create a more accurate risk rating for the relevant firm according to the changing firm-specific or macroeconomic variables [20]. At this point, this study is expected to contribute positively to the related literature by assaying whether firm-specific and macroeconomic variables affect the financial distress risk of the listed SMEs. Within the scope of the study, the annual data of 31 firms listed in Borsa Istanbul (BIST) SME Industrial Index over the period from 2010 to 2019 have been analyzed by applying panel data analysis (generalized method of moments) with 310 observations.

The remainder of the study frames as follows: section 2 explains the concept and causes of financial distress. Section 3 discusses the literature review of financial distress risk measurement and its determinants. Section 4 explains the statistical methodology (panel data analysis), introduces the generated model and provides the empirical results of the study. Finally, Section 5 summarizes the conclusion of the study.

\section{Financial Distress: Term and Causes}

Financial distress is described as the last stage in which a firm goes into decline and occurs before the events such as bankruptcy or liquidation. Signals received for financial distress may direct firms to take a decision to merge with a better managed or more solvent firm and act as an early warning, allowing timely and adequate measures to be taken against future bankruptcy [27].

The concept of financial distress includes four basic concepts, failure (economic and financial), insolvency, default (technical and legal) and bankruptcy. Economic failure can be defined as a remarkable and continuous decline in the rate of return on capital invested in an investment field with a certain level of risk from the rate of return on alternative investments with equivalent risk. Financial failure is the situation where the actual cash flow value is lower than the expected value, in other words, inability to meet short-term debts that need to be paid. Insolvency refers to the inability of a firm to meet its short-term debts in a technical sense and it also refers to the situation that a firm's total debts exceed its' total assets and hence negative real net worth in a bankruptcy sense. Technical default arises when the debtor breaches one of the terms of the agreement with the creditor. Legal default refers to the failure to meet the periodic obligations such as scheduled loan or bond payment. Bankruptcy is a leading indicator that the firm is in financial distress and entails a formal declaration of bankruptcy including the courts [3].

Considering the formation process of financial distress; the normal operating cycle of a firm may be disrupted by a number of internal, external, and global factors. In this case, firms take the required measures by considering these problems. As a result of the measures taken, the business may return to its normal process, the process may continue because the measures taken are insufficient, or it may be switched to another business line instead of the main field of operations, or it may be reorganized. If the measures taken are insufficient, external measures and agreements are applied and some solutions such as rehabilitation, branch closure, mergers, and sales are sought. As a result of these external measures, the business either returns to its' normal process or ceases to operate, becomes bankrupt or liquidated. The reasons for financial distress may be caused by the variables that business management can control, as well as by external environment variables that business management cannot interfere with too much. Some of them are as follows and all interact with each other [8]: 


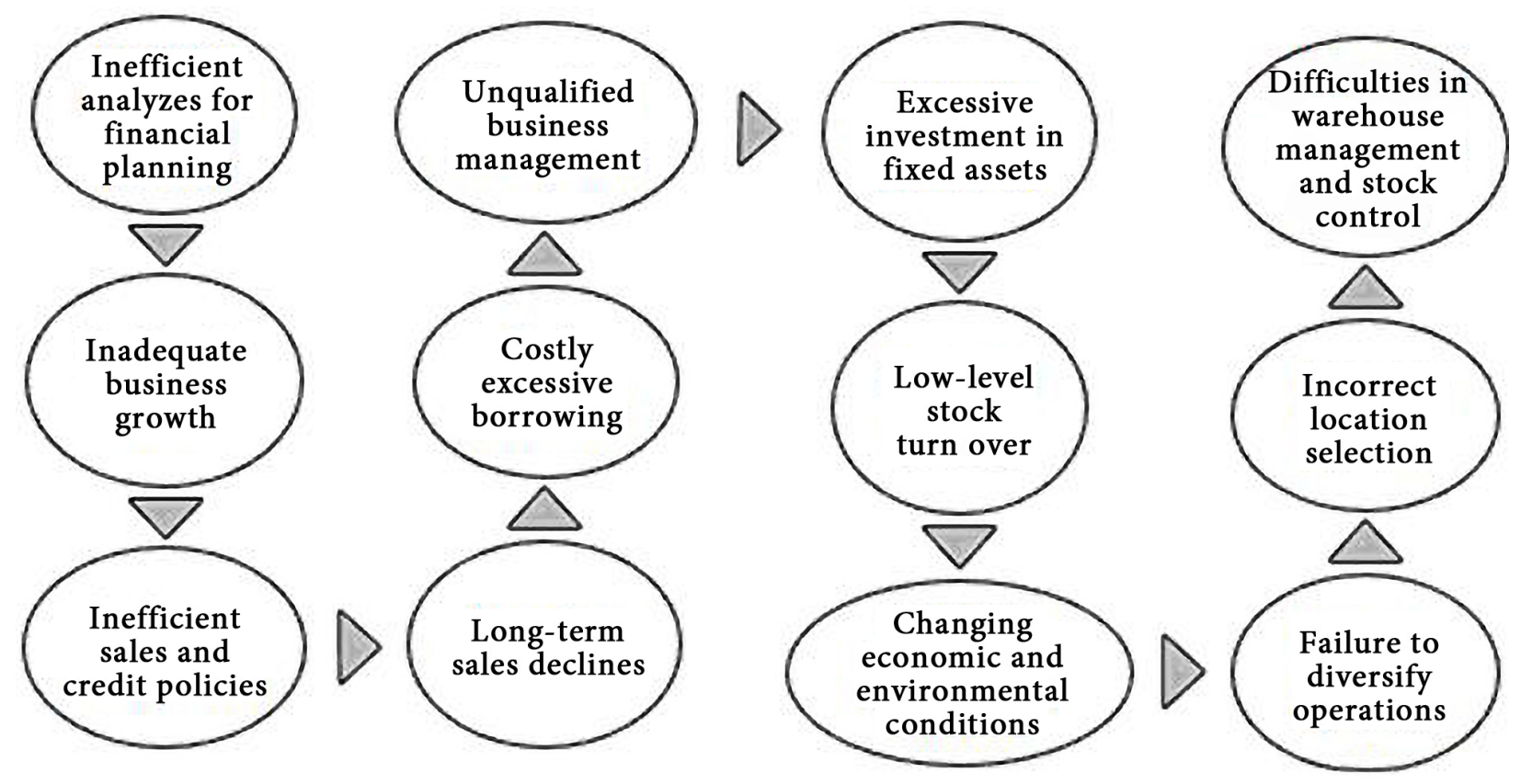

Source: Created by the author, based on [8].

Figure 1. Main Causes of Financial Distress

It is possible to classify the causes of financial distress as internal (firm-specific factors) and external (industry-specific and macro-specific factors) categories. Firm-specific factors include financial factors, corporate governance factors and productivity factors. Industry-specific factors consist of customers, suppliers, new entrants, substitutes, and the competition environment. Macro-specific factors are political, economic, social, and technological events [23].

The causes of financial distress have been also defined by some studies in the literature by considering different criteria. For example, Whitaker (1999) adopted the definition of financial distress as the cash flow less than long-term liabilities due. According to Whitaker (1999); the main causes of financial distress consist of poor management (a downtrend in the ratio of the operating profits of the firm to the operating profits of the sector on a five-year period)or/and economic distress (a decrease in operating profits of the sector). At this point, management activities are considered as a critical determinant of recovering from financial distress for the firms entering financial distress as a result of mismanagement, not of economic distress [37]. According to Pálinkó and Svoób (2016); financial distress may occur after three important situations: inappropriate asset allocation, high financial leverage, and liquidity shortage. When operational asset efficiency is insufficient, this situation leads to value destruction, and then the asset structure of the company deteriorates and financial leverage increases. The deteriorating financial structure puts the company in liquidity shortage and financial distress arises as a result of this situation [26].

Financial distress creates significant costs for the firms, such as losing important non-financial stakeholders (customers, suppliers, employees, etc.), violating contract terms or missing principal/coupon payments, and not being able to place the projects with positive net present value. The contract violations bring along several situations such as financial penalties, accelerated repayments, reduced operational flexibility, and management having to bear high costs in terms of both time and resources to eliminate these problems [28]. Financial distress also creates a significant cost by disrupting the optimal capital structures of firms. Firms may act against the interests of both financial and non-financial stakeholders, and their access to finance may be damaged. In addition, the situation faced by companies experiencing financial difficulties may encourage their competitors to gain more market shares by taking an advantage of this situation, which creates an important cost element for companies [24].

It is also possible to address financial distress costs in two ways, direct and indirect [3]: 

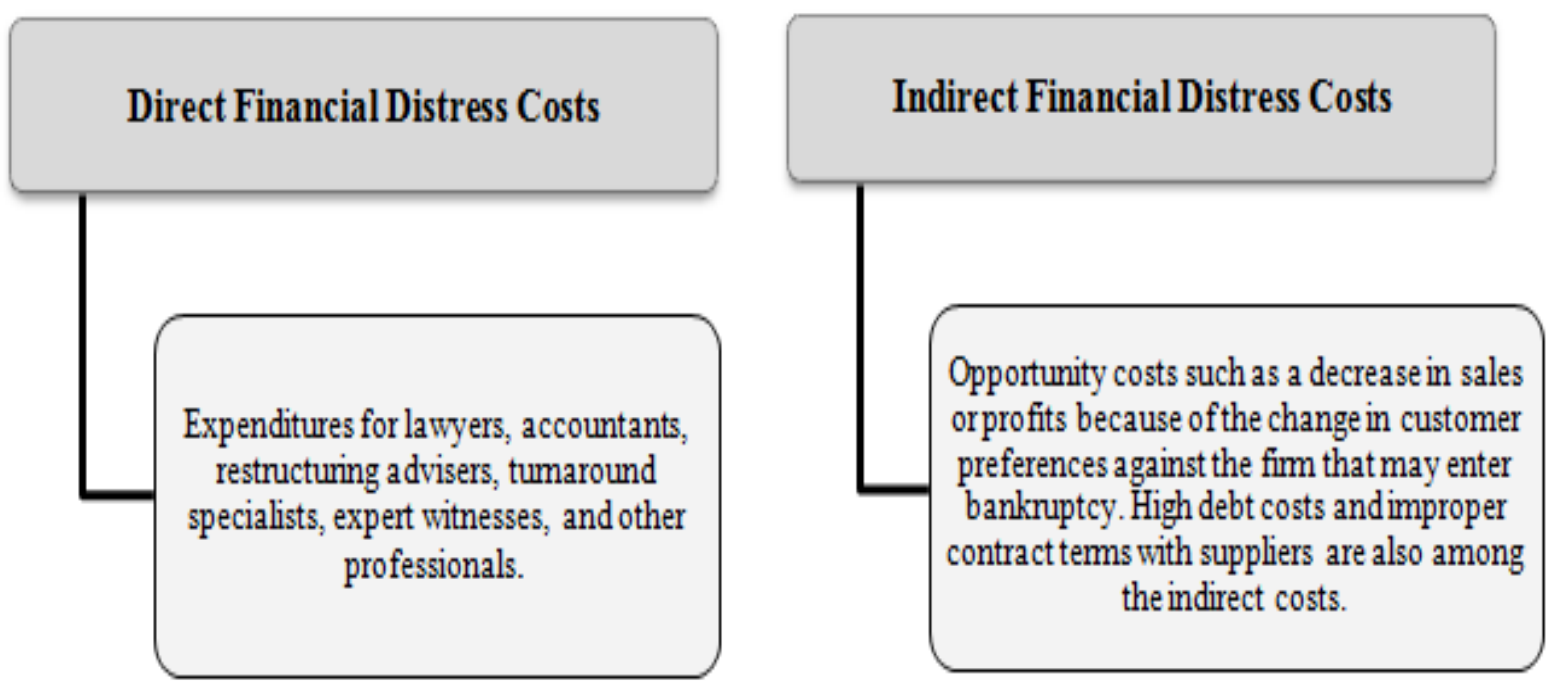

Source: Created by the author, based on [3].

Figure 2. Financial Distress Costs

When firms begin to receive signals of financial distress, they make great efforts to take required precautions and avoid bankruptcy to correct this situation. They resort to many alternatives such as renewal of asset and liability structure, asset sales, reduction in capital expenditure, layoffs, and restructuring of public or bank debts. The approaches of banks to the firms in financial distress may take different forms. Some banks may choose to loosen financial constraints on the firms in financial distress by delaying principal and interest payments, providing new financing opportunities, and waiving contracts. Some banks, on the other hand, tighten their financial restrictions on the so-called firms by accelerating principal and interest payments, lowering credit limits and increasing the amount of collateral. Although asset sales are another method used by firms in financial distress, they are subject to some restrictions depending on sectoral factors or performance level. It is not easy for firms operating in sectors with high operating leverage or with low performance to resort to asset sales [7].

\section{Literature Review}

Many empirical studies have dealt with the financial distress of SMEs, which have a vital importance in the economic growth of countries and these studies provided several empirical evidences that financial distress emerged because of both internal (profitability, liquidity, efficiency, leverage, etc.) and external (macroeconomic or industrial) factors:

Jahur and Quadır (2012) did a research related to the causes of financial distress of 20 SMEs in Bangladesh over the 2004-2008 periods. The financial distress degree of the SMEs was assessed through Altman Z-Score method and Varimax Rotated Factor analysis were employed for identifying the causes of financial distress. The empirical results showed that poor accounting system, sensitivity to the government policy change, productivity and profitability, fund management and credit crunch, liquidity, macroeconomic factor, management succession, and financial control were the main causes of financial distress. In the same vein, Maricica and Georgeta (2012) investigated the forecasting ability of financial ratios for 2009 and 2010. Considering a sample of 63 listed Romanian firms, several financial ratios categories such as size, return and margin, liquidity, financial position, cash-flow, earnings, indebtedness and capital structure, credit back payment, and interest payment capacity and ratios in Altman's model were used. According to the t-test results; some differences were observed among the analyzed firms in terms of profitability and return, financial position, indebtedness, and capital structure.

A research by Abdullah et al. (2014) dealt with the prediction of the factors leading to the financial distress of production SMEs in Malaysia. The study employed logistic regression (forward stepwise method) for the period 2000-2010. The empirical results showed that firm age, firm size, liability ratio, sales to total assets, and net profit to share capital were significantly different between distressed and non-distressed SMEs for the 4-year prior. It was also seen that firm age, current ratio, earnings before interest and tax (EBIT) to total assets, and net profit to share capital could estimate the financially distressed firms for 3-year prior. Considering 2-year and 1-year prior to distress, total debts to total assets, earnings before interest and tax to total assets and net profit to share capital were determined as the factors that differ between the distressed and non-distressed SMEs.

In another study by Selassie et al. (2016), on the analysis of the financial healthiness of 30 selected SMEs operating in the manufacturing, trade, and service sector in Wolaita Altman Z-Score method was used for the year of 2015. According to the results; 3 SMEs in the service sector, 1 SME in the manufacturing sector and 3 SMEs in the trade sector were found to be financially distressed. Additionally; 
Multiple Discriminate Analysis showed that sales ratio, working capital and EBIT affected the financial health of the SMEs to a great extent.

Similarly, Yazdanfar and Öhman (2019) sought to bring out the determinants of financial distress of non-financial SMEs from 2008 to 2015. The study employed a multiple binary logistic regression method by considering macroeconomic dummy variable, firm-specific variables, and an industry-specific variable to analyze a panel data set of 3865 Swedish SMEs. In their study, findings revealed that macroeconomic conditions (global financial crisis) and firm-specific variables such as performance, financial leverage and lagged financial distress had a significant effect on financial distress.
Charalambakis and Garrett (2019) investigated the principal determinants of financial distress risk for 31.000 Greek private firms during 2003-2011. They implemented a multiperiod logit model and the empirical findings indicated that the financial distress for the analyzed firms was determined by profitability, leverage, retained earnings to total assets, size, liquidity ratio, an export dummy variable, the tendency to pay out dividends and the growth rate in real GDP.

Additionally, several studies address the determinants of the financial distress risk of the firms of various sizes, especially in the manufacturing sector in many countries, including the United Kingdom, Malaysia, Australia, Turkey, Indonesia, Nigeria, and China:

Table 1. Literature Review on the Financial Distress

\begin{tabular}{|c|c|c|c|c|c|}
\hline Author & Period & Sample & Method & $\begin{array}{l}\text { Financial distress } \\
\text { indicator }\end{array}$ & Results \\
\hline $\begin{array}{l}\text { Liou and } \\
\text { Smith, } \\
2006\end{array}$ & $\begin{array}{c}1981 \\
- \\
2001\end{array}$ & $\begin{array}{l}340 \text { Production } \\
\text { Firms Listed in } \\
\text { the London } \\
\text { Stock } \\
\text { Exchange }\end{array}$ & $\begin{array}{l}\text { A Linear } \\
\text { Discriminant } \\
\text { Model }\end{array}$ & Taffler Z-Score & $\begin{array}{l}\text { Macroeconomic variables have a } \\
\text { considerable impact on the identification } \\
\text { of financial distress, but their value has a } \\
\text { low explanatory power }\end{array}$ \\
\hline $\begin{array}{l}\text { McNamara } \\
\text {, Duncan } \\
\text { and Kelly, } \\
2011\end{array}$ & $\begin{array}{c}1985 \\
- \\
2000\end{array}$ & $\begin{array}{l}92 \text { Firms } \\
\text { Listed in the } \\
\text { top } 500 \text { of the } \\
\text { Australian } \\
\text { Stock } \\
\text { Exchange }\end{array}$ & Logit Analysis & $\begin{array}{c}46 \text { failed and } 46 \\
\text { non-failed companies } \\
\text { are matched with each } \\
\text { other according to the } \\
\text { basis of industry } \\
\text { membership and total } \\
\text { assets }\end{array}$ & $\begin{array}{l}\text { A Two-Year Lag in Interest Rates, } \\
\text { One-Year Lag in Change in GDP, } \\
\text { Changes in Corporate } \\
\text { Profits Before Tax and Acid-Test Ratio } \\
\text { have a significant impact on financial } \\
\text { distress }\end{array}$ \\
\hline $\begin{array}{l}\text { Thim, } \\
\text { Choong } \\
\text { and Nee, } \\
2011\end{array}$ & $\begin{array}{c}2005 \\
- \\
2009\end{array}$ & $\begin{array}{c}101 \\
\text { Companies } \\
\text { Listed in Kuala } \\
\text { Lumpur Stock } \\
\text { Exchange }\end{array}$ & $\begin{array}{l}\text { Panel Data } \\
\text { Regression } \\
\text { Analysis }\end{array}$ & $\begin{array}{l}\text { Long-Term Debt to } \\
\text { Total Equity Ratio and } \\
\text { Short-term Debt to } \\
\text { Total Equity Ratio }\end{array}$ & $\begin{array}{l}\text { Size and interest coverage ratio have a } \\
\text { positive impact, growth of operating } \\
\text { profits has a negative impact on financial } \\
\text { distress. }\end{array}$ \\
\hline $\begin{array}{l}\text { Akpinar } \\
\text { and } \\
\text { Akpinar, } \\
2017\end{array}$ & $\begin{array}{c}2010 \\
- \\
2014\end{array}$ & $\begin{array}{l}82 \text { Production } \\
\text { Firms Listed in } \\
\text { Borsa Istanbul }\end{array}$ & $\begin{array}{l}\text { Panel Data } \\
\text { Regression } \\
\text { Analysis }\end{array}$ & Altman Z-Score & $\begin{array}{l}\text { Leverage, size and dividend payment } \\
\text { have a negative impact on financial } \\
\text { distress Profitability, age, firm value and } \\
\text { intellectual capital have a positive impact } \\
\text { on financial distress }\end{array}$ \\
\hline $\begin{array}{l}\text { Darmawan } \\
\text { and } \\
\text { Supriyanto, } \\
2018\end{array}$ & $\begin{array}{c}2011 \\
- \\
2014\end{array}$ & $\begin{array}{l}119 \text { Mining } \\
\text { Firms Listed } \\
\text { on the } \\
\text { Indonesian } \\
\text { Stock } \\
\text { Exchange }\end{array}$ & $\begin{array}{c}\text { Multiple } \\
\text { Linear Regression } \\
\text { Test }\end{array}$ & $\begin{array}{l}\text { Altman } \\
\text { Z- Score }\end{array}$ & $\begin{array}{l}\text { Each financial ratio has a positive effect } \\
\text { on financial distress }\end{array}$ \\
\hline $\begin{array}{l}\text { Ikpesu, } \\
2019\end{array}$ & $\begin{array}{c}2010 \\
- \\
2017\end{array}$ & $\begin{array}{l}18 \text { Production } \\
\text { Firms Listed in } \\
\text { Nigeria Stock } \\
\text { Exchange }\end{array}$ & $\begin{array}{l}\text { Fully Modified } \\
\text { Ordinary Least } \\
\text { Square Method }\end{array}$ & Altman Z-Score & $\begin{array}{l}\text { Leverage, profitability, firm size has a } \\
\text { positive, revenue growth, share price } \\
\text { have a negative impact on financial } \\
\text { distress }\end{array}$ \\
\hline $\begin{array}{c}\text { Arilyn, } \\
2020\end{array}$ & $\begin{array}{c}2003 \\
- \\
2018\end{array}$ & $\begin{array}{l}7 \text { Agriculture } \\
\text { Firms Listed in } \\
\text { the Indonesia } \\
\text { Stock } \\
\text { Exchange }\end{array}$ & $\begin{array}{l}\text { Stepwise Logit } \\
\text { Analysis }\end{array}$ & $\begin{array}{l}\text { Firms are marked with } \\
1 \text { and said to experience } \\
\text { financial distress if the } \\
\text { event occurs; the others } \\
\text { are marked with } 0 .\end{array}$ & $\begin{array}{l}\text { Each independent variable has a positive } \\
\text { impact on financial distress }\end{array}$ \\
\hline
\end{tabular}


As can be seen from Table 1, there are numerous studies involving many sectors on determining factors of financial distress. Looking at the association between macroeconomic variables and financial distress, it is observed that several macroeconomic variables such as GDP, inflation, interest rates, and exchange rate have a statistically significant effect on financial distress, but some of them have a low level of effect and some are high $[6,17,20,34]$. Considering the factors affecting financial distress at the firm level, such as financial ratios, it is seen that the financial variables such as liquidity, profitability, and firm value have a positive effect, while variables such as leverage, size, and dividend payment have a negative effect on financial distress $[2,16,25,39]$.

\section{Materials and Method}

The purpose of this study is to investigate the numerical link between financial distress risk and its firm-specific and macroeconomic determinant factors that may affect it. After testing the financial distress risk by using Springate S-Score method, the impact of determinant factors on financial distress is determined by panel data analysis. For the analysis, secondary data issued over the period from 2010 to 2019 and a ten-year panel data are acquired from the annual financial statements of the 31 firms listed in BIST SME Industrial Index (A total of 41 firms are included in BIST SME Industrial Index, but 10 firms are excluded from the analysis because their data could not be fully available in the 2010-2019 period). The data as to macroeconomic variables are collected from the official websites of the Turkish Statistical Institute and The Central Bank of the Republic of Turkey.

As can be seen from Figure 3; among the 31 firms, 8 firms are in the chemicals, petroleum, rubber, and plastic products sector; 4 firms are in fabricated metal products machinery electrical equipment, and transportation vehicles sector; 4 firms are in the textile, wearing apparel and leather sector; 3 firms are in the basic metal sector; 3 firms are in paper and paper products, printing and publishing sector; 2 firms are in non-metallic mineral products sector; 5 firms are in food, beverage, and tobacco sector; 1 firm are in agriculture, forestry and fishing sector and 1 firm is in mining and quarrying sector.

The dependent variable employed in the study is the Springate S-Score used in measuring financial distress risk. The improved version of Altman's Z-Score model is Springate S-Score model and it was first introduced by Gordon LV Springate (1978). Developed by choosing 4 out of 19 financial ratios that have become popular in Altman's $\mathrm{Z}$ score model, the $\mathrm{S}$ score model was tested on 40 companies and achieved an accuracy rate of $92.5 \%$. In the setup of the Springate S score model, there are 4 financial ratios and coefficients determining their weights. As in Altman's Z-Score model, S score is obtained by multiplying each financial ratio with these determined weights and adding them in this model. The function for the $\mathrm{S}$ score can be expressed as follows:

$$
\begin{aligned}
& \text { S score }=1.03 \mathrm{X}_{1}+3.07 \mathrm{X}_{2}+0.66 \mathrm{X}_{3}+0.4 \mathrm{X}_{4} \\
& \mathrm{X}_{1} \mathrm{X}_{1}=\text { Working capital / Total assets } \\
& \mathrm{X}_{2}=\text { Profit before interest and tax / Total assets } \\
& \mathrm{X}_{3}=\text { Profit before interest and tax / Short-term debt } \\
& \mathrm{X}_{4}=\text { Sum of Sales / Total assets }
\end{aligned}
$$

If the $\mathrm{S}$ score calculated in line with the above equation is $<0.862$, it is accepted that firms have a high probability of bearing financial distress and bankruptcy costs and that they are financially unsuccessful. On the other hand, having an $\mathrm{S}$ score above this value indicates that companies are less likely to face financial distress and bankruptcy costs and are financially successful [32]. The S scores of the 31 firms included in the analysis for 2010-2019 are shown in Figure 4:

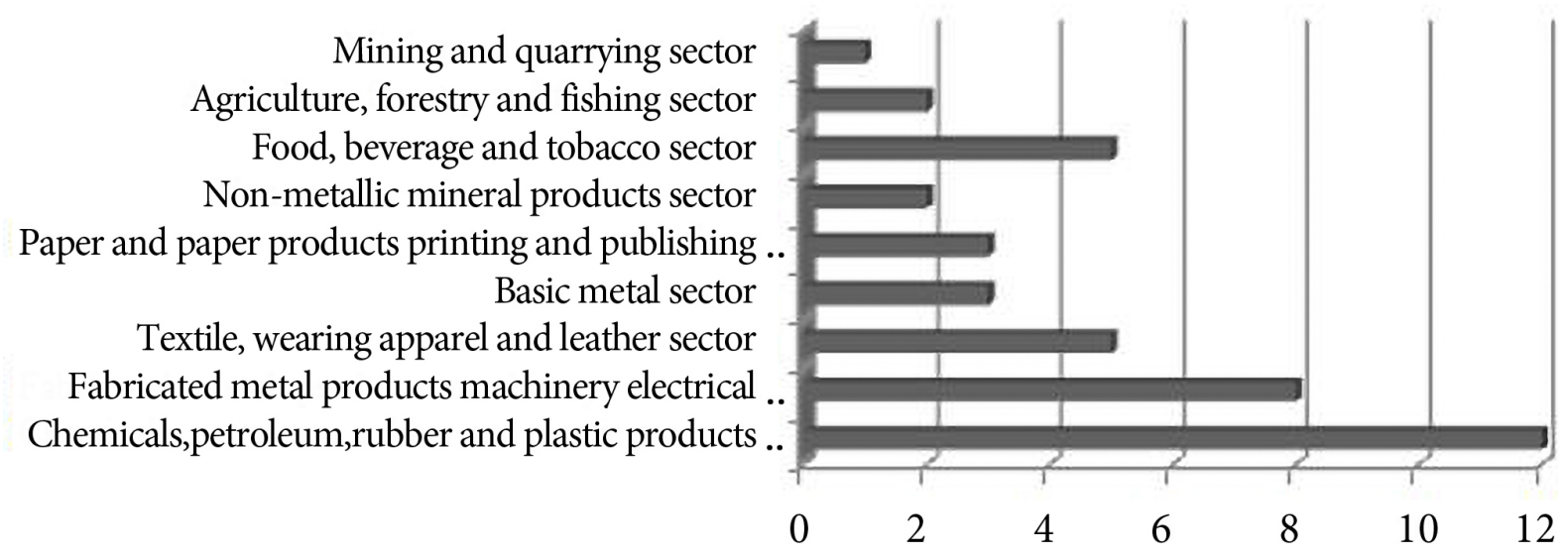

Figure 3. Sectoral Distribution of the SMEs Listed on BIST SME Industrial Index 

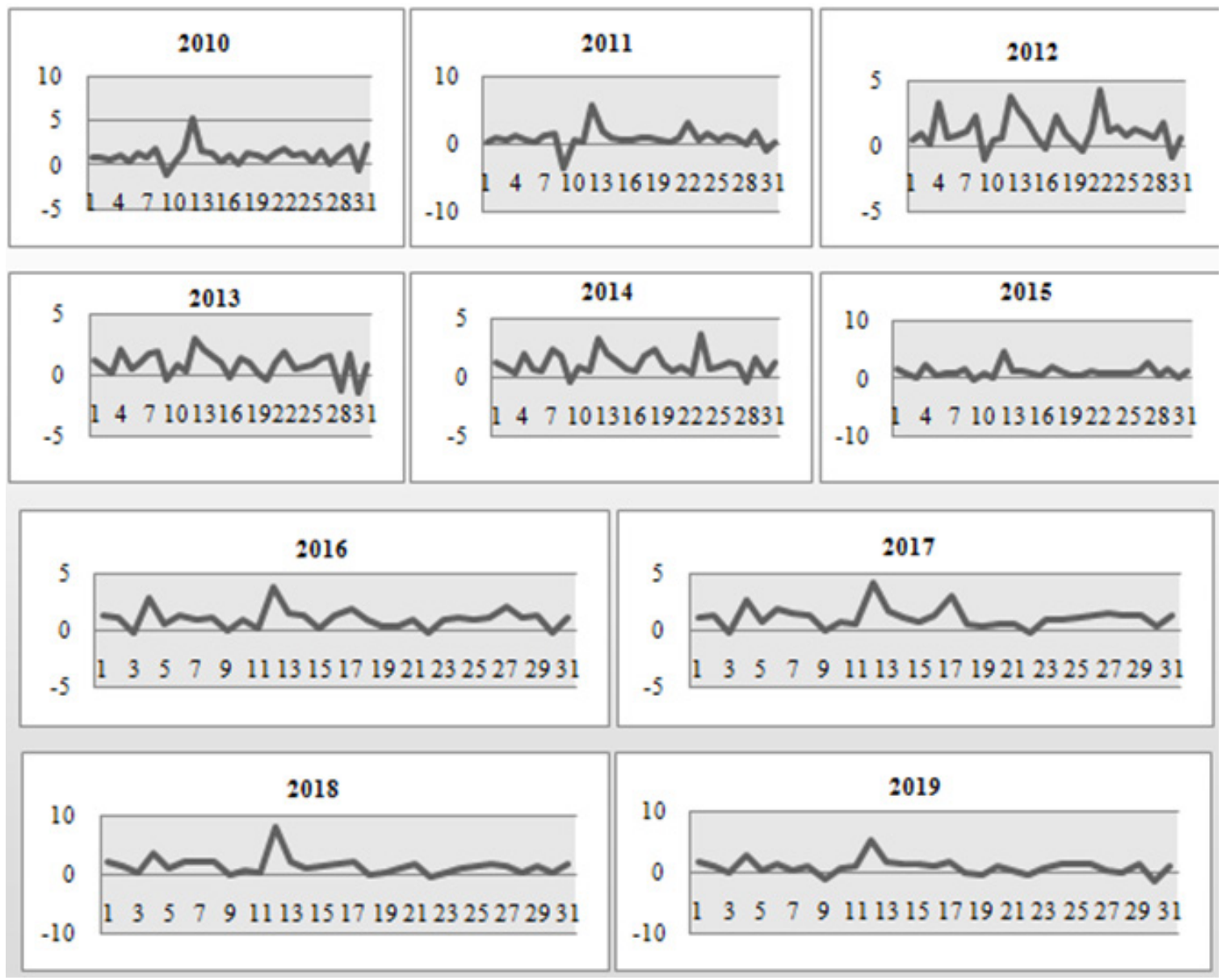

Source: Created by the author.

Figure 4. Springate S-Score Levels of the SMEs by Years

Figure 4 shows that $\mathrm{S}$ scores for 11 of the 31 firms included in the analysis are less than 0.862 . At this point, it is possible to state that the firms in question $(<0.862)$ are likely to face with financial distress. It is also seen that 1 firm in 2015, 2 firms in 2011, 2014, and 2017, 3 firms in 2010 and 2018, 4 firms in 2012 and 2016, and 5 firms in 2013 and 2019 have received negative values.
In order to analyze the effect of firm-specific and macroeconomic factors on financial distress risk, Stata version 15 is used. In determining the firm-specific and macroeconomic factors, widely used variables determining financial distress risk in both domestic and international studies are considered $[2,6,11,16,17,20,22,25,34,39$, 41]. The description of all independent variables used in the analysis is presented in Table 2: 
Table 2. Variables description

\begin{tabular}{ccc}
\hline Variables & Symbol & Description \\
\hline Financial distress & Dependent variable & Springate S score \\
\hline Current ratio & S score & Firm-specific variables \\
\hline Quick ratio & CR & Ratio of total assets to current liabilities \\
\hline Asset turnover & QR & Ratio of quick assets total to current liabilities \\
\hline Debt ratio & ATO & $\begin{array}{c}\text { Ratio of total sales to } \\
\text { total assets }\end{array}$ \\
\hline Financial leverage & DR & $\begin{array}{c}\text { Ratio of total debt to } \\
\text { total assets }\end{array}$ \\
\hline Return on assets & LEV & Ratio of total debt to shareholder's equity \\
\hline Economic growth & ROA & $\begin{array}{c}\text { Ratio of net income to } \\
\text { total assets }\end{array}$ \\
\hline Exchange rate & Macroeconomic variables & Gross domestic product growth rate \\
\hline Inflation & GDP & Real effective exchange rate of USD to TL \\
\hline
\end{tabular}

In order to examine the firm-specific and macroeconomic determinants of financial distress risk, the dynamic panel equations for the estimation are as follows:

$$
\mathrm{S} \text { scoreit }=\beta \mathrm{i} \text { S scoreit- } 1+\alpha \mathrm{itXit}+\mu \mathrm{i}+\phi \mathrm{t}+\varepsilon \mathrm{it}
$$

Where $i$ denotes ith firm $(i=1 \ldots N)$ and $t$ denotes th year $(t=1 \ldots T)$. Where $S$ score $_{i t}$ stands for the Springate $S$ score of firm $\mathrm{i}$ at the end of period $\mathrm{t}, \mathrm{X}_{\mathrm{it}}$ is a vector of other control variables hypothesized to affect $\mathrm{S}$ score. While, $\mu_{i}$ measures firm-specific effects, $\varepsilon_{i t}$ denotes the idiosyncratic shocks, and varies across firms $i$ and time periods $t$. Finally, time dummies are included in the regression $\phi_{t}$ to control for the time-specific effects and to eliminate cross-sectional dependence in the data [29].

In this study, one-step system generalized method of moments (GMM) is used because the number of firms is greater than the number of periods. The reason why this method is preferred is the fact that two-step GMM estimators from finite samples are downward biased and take into account the limited number of firm observations [9]. The lagged value of the dependent variable is predetermined in the model, and the control variables are accepted endogenous. In addition, this method provides more consistent and effective parameter estimates compared to other panel data models. System GMM method was developed by Arellano and Bover (1995) and Blundell and Bond (1998) and it is known as an effective method in overcoming bias and potential endogeneity problems of estimators in panel data models. In order to ensure consistency in the system GMM model, the second-order error term, AR (2), should not be present, so Arellano and Bond (1991) tests are used in the analysis. The error terms should be unrelated to the instruments, so Hansen's (1982) test, which reports p probability values for over-descriptive constraints, has been used. In addition, to avoid finite sample bias, the number of instrument variables should be equal to or smaller than the number of groups. Hansen difference tests are also applied for the validity of additional moment conditions. In the analysis, the collapse suboption for the xtabond 2 command in STATA is used to deal with too many instruments [30].

\section{Results and Discussion}

Table 3 summarizes the basic statistics for the series in the study. The total of observations sums to $n=310$, for a period of 10 years: 
Table 3. Descriptive statistics

\begin{tabular}{|c|c|c|c|c|c|}
\hline Variable & Obs. & Mean & Std. Dev. & Min & Max \\
\hline S score & 310 & 1.117 & 1.109 & -3.452 & 7.921 \\
\hline CR & 310 & 2.826 & 3.826 & 0.032 & 43.864 \\
\hline QR & 310 & 2.069 & 3.319 & 0.031 & 35.682 \\
\hline ATO & 310 & 0.722 & 0.453 & 0 & 2.441 \\
\hline DR & 310 & 1.229 & 6.664 & -65.656 & 78.662 \\
\hline LEV & 310 & 0.469 & 0.276 & 0.017 & 1.707 \\
\hline ROA & 310 & 0.015 & 0.125 & -0.342 & 0.995 \\
\hline EXC & 310 & 14.235 & 9.537 & -3.018 & 31.959 \\
\hline CPI & 310 & 9.838 & 3.193 & 6.472 & 16.332 \\
\hline GDP & 310 & 5.863 & 2.937 & 0.917 & 11.201 \\
\hline
\end{tabular}

The value of S score varies between -3.45 percent and 7.92 percent and the average is 1.12 percent. The mean value of $\mathrm{CR}, \mathrm{QR}$, and ATO are 2.826, 2.069, and 0.722 respectively. The value of the standard deviation for CR, QR, and ATO are $3.826,3.319$, and 0.453 respectively. It may be concluded that the analyzed firms have a sufficient level of liquidity, but asset turnover is somewhat low. The lowest values of DR and LEV are -65.656 and 0.017 and the highest values are78.662 and 1.707, while the overall average values are 1.229 and 0.469 with a standard deviation of 6.664 and 0.276 respectively. This indicates that the borrowing level is at reasonable levels and that approximately half of the current assets are financed by foreign resources (debt). Other descriptive statistics for the rest of the variables can be observed from Table 3.

Table 4. Correlation Matrix

\begin{tabular}{|c|c|c|c|c|c|c|c|c|c|c|}
\hline & Score & $\mathrm{CR}$ & $\mathrm{QR}$ & ATO & $\mathrm{DR}$ & LEV & ROA & EXC & CPI & GDP \\
\hline Score & 1 & & & & & & & & & \\
\hline $\mathrm{CR}$ & 0.35 & 1 & & & & & & & & \\
\hline $\mathrm{QR}$ & 0.41 & 0.97 & 1 & & & & & & & \\
\hline ATO & 0.59 & -0.1 & -0 & 1 & & & & & & \\
\hline DR & 0.01 & -0.1 & -0.1 & 0.04 & 1 & & & & & \\
\hline LEV & -0.12 & -0.6 & -0.5 & 0.24 & 0.11 & 1 & & & & \\
\hline ROA & 0.68 & 0.32 & 0.37 & 0.27 & -0.1 & -0.4 & 1 & & & \\
\hline EXC & 0.08 & -0.1 & -0 & 0.01 & 0.04 & -0 & 0.07 & 1 & & \\
\hline CPI & 0.07 & -0.1 & -0.1 & 0.03 & 0.13 & 0.05 & 0.07 & 0.61 & 1 & \\
\hline GDP & -0.04 & 0.05 & 0.04 & 0.03 & -0.1 & 0.01 & -0.04 & -0.4 & -0.7 & 1 \\
\hline
\end{tabular}

As indicated in Table 4, there is a multicollinearity problem between the current ratio and quick ratio. Hence, two different models are estimated by considering the so-called variables one by one in the analysis. The empirical findings based on one-step system GMM estimations are presented in Table 5: 
Table 5. One-Step System GMM estimates from a panel of 10-year span data

\begin{tabular}{lll}
\hline Dependent variable: S score & -1 & -2 \\
S score (-1) & $0.289(0.172)$ & $0.302(0.149)$ \\
ATO & $0.782(0.001)^{* * *}$ & $0.766(0.001)^{* * *}$ \\
DR & $0.004(0.009)^{* * *}$ & $0.003(0.013)^{* *}$ \\
LEV & $0.464(0.080)^{*}$ & $0.495(0.057)^{*}$ \\
ROA & $3.317(0.079)^{*}$ & $3.440(0.071)^{*}$ \\
EXC & $0.006(0.277)$ & $0.005(0.414)$ \\
CPI & $-0.027(0.046)^{* *}$ & $-0.028(0.031)^{* *}$ \\
GDP & $-0.014(0.315)$ & $-0.016(0.230)$ \\
QR & $0.083(0.004)^{* * *}$ & \\
CR & & $0.069(0.003)^{* * *}$ \\
Time Dummies & Yes & Yes \\
Observations & 310 & 310 \\
Instruments & 23 & 23 \\
Number of Groups & 31 & 31 \\
AR (1) p-value & 0.007 & 0.005 \\
AR (2) p-value & 0.186 & 0.197 \\
Sargan Test (p-value) & 0.000 & 0.000 \\
Hansen Test (p-value) & 0.168 & 0.163 \\
The difference in Hansen Test (p-value) & 0.178 & 0.177 \\
\hline
\end{tabular}

Notes: Macroeconomic variables (EXC, CPI, and GDP) are year-to-year percentage change rate and other variables are ratio. All estimators are robust to heteroscedasticity and autocorrelation. Windmeijer (2005) finite sample correction for standard errors is employed. I report one-step GMM estimators. " $(-1)$ " denotes the lag of the corresponding variable. P-values are in parentheses. The significance of $\mathrm{p}$-values is reported as follows: ${ }^{*} \mathrm{p}<.1,{ }^{* *} \mathrm{p}<.05$, $* * * \mathrm{p}<.01$.

The diagnostic tests demonstrate the following findings. To confirm the validity of the econometric assumptions, the Arellano-Bond test is used to check the hypothesis that error terms are not serially correlated. It is concluded from the $\mathrm{p}$-value that there is no second-order serial correlation in the error terms and each model has passed the AR (2) tests. The number of instrumental variables is less than the number of firms and the validity of the instrumental variables is confirmed, as can be seen from the p-values of the Hansen $\mathrm{J}$ test and Difference-in-Hansen test for moment constraints additional. At this point, it is possible to state that the estimated models are adequately specified by considering all the test statistics of these models [35].

As mentioned above, the Springate $\mathrm{S}$ score, which is an indicator of financial distress risk, is used as a dependent variable in the estimated models. An increase in this score means that the risk of financial distress of firms decreases, and vice versa, the risk of financial distress increases. Therefore, as part of the results obtained from the models created, it is evaluated that any independent variable positively affects the $\mathrm{S}$ score by decreasing the risk of financial distress, and negatively affects by increasing the risk in question. As can be seen from Table 5, the main estimation results of one step-GMM reveal the following. CR, QR, ATO, LEV, ROA, and CPI are persistently significant for all the models. According to the Hansen test, the instruments used for system-GMM are confirmed in both models. Regarding the firm-specific variables; the estimation results show that ROA is statistically significant at the conventional level and that has a positive impact on the $\mathrm{S}$ score. This positive effect of profitability is expected and similar findings have been obtained in the previous literature $[11,25]$. Also, $\mathrm{CR}$ and $\mathrm{QR}$, proxies for the liquidity, affect $\mathrm{S}$ score positively, which results are consistent with the former studies $[19,36,15,18]$. It can be also observed that, as an indicator of turnover ratio, ATO has a statistically significant positive impact on S score at the $\% 1$ significance level as well. DR and LEV, individually, have positive impacts on S score. Also, in line with the previous literature, CPI has a negative impact on the $\mathrm{S}$ score, indicating that a $1 \%$ increase in inflation rates reduces the S score by approximately $3 \%$ in both models $[6$, $16,39]$. Finally, the estimates reveal that there is no impact of EXC and GDP on the S score.

\section{Conclusion}

This study aims to determine the firm-specific and macroeconomic factors that influence the financial distress risk of the firms listed in the Borsa Istanbul SME Industrial Index between 2010 and 2019. For this purpose, Springate $\mathrm{S}$ score as an indicator of financial distress risk; current ratio, quick ratio, asset turnover, debt ratio, leverage ratio and return on assets as firm-specific factors and economic growth, inflation, and exchange rate as macroeconomic 
factors are analyzed with one-step system generalized method of moments (GMM).

Main estimation results show that each firm-specific factor has a positive impact on financial distress risk and that there is also a statistically significant relationship between $\mathrm{S}$ score and inflation as a macroeconomic factor. The findings obtained from the study are often in parallel with the expectations. For instance, the profitability of the firm increases the $\mathrm{S}$ score and makes it possible to reduce the risk of financial distress. A long-term lack of liquidity and the inability to find a solution may initiate the bankruptcy process, so an increase in liquidity is expected to reduce the risk of financial distress. In the same vein, the low asset turnover rate shows that the firm has a high financial distress risk. At this point, it is expected that as the asset turnover rate increases, the $\mathrm{S}$ score increases and therefore the risk of financial distress decreases. Also, financial distress may occur due to the excessive use of foreign resources by the firms. High-rate indebtedness indicates that the firm may be in trouble and carries risk during the obligation to repay interest and principal. On the other hand, firms use debt to make high profits and provide their shareholders with high returns. At this point, it is of great importance for the firms to have a leverage ratio suitable for their financing structures. In case of the optimal composition of capital, it may be normal for an increase in the debt ratio and leverage ratio to increase the $\mathrm{S}$ score and reduce the risk of financial distress. On the other hand, during the inflationary periods, firms' price policies become uncertain and financing costs rise. In addition, in a situation where inflation rates are high, increasing risk and uncertainty prevents rational investment decisions. Therefore, it is an expected result that the inflation rate increases the risk of financial distress of the firms.

Based on the findings obtained, it is possible to express that internal and external factors should be monitored very carefully so as to protect against the negative effects of financial distress. The findings obtained from this study show that it is extremely significant to keep the liquidity level of the SMEs at reasonable levels, to create an optimal capital structure and to carefully monitor the developments in the macroeconomic environment in which they operate.

\section{REFERENCES}

[1] N. A. H. Abdullah, N. Zainudin, A. H. Ahmad, and R. M. Rus. Predictors of financially distressed small and medium-sized enterprises: a case of Malaysia, 3rd International Conference on Economics and Finance Research, Conference Paper, Seoul, South Korea, 108-112, 2014.

[2] O. Akpinar, G. Akpinar. The determinants of financial distress: an application on Borsa Istanbul, Journal of Business Research, Vol. 9, No. 4, 932-951, 2017.
[3] E. I. Altman, E. Hotchkiss. Corporate financial distress and bankruptcy, 3rdedition, New Jersey: Willey Publishing, 2006.

[4] M. Arellano, S. Bond. Some tests of specification for panel data: Monte Carlo evidence and an application to employment equations, Review of Economic Studies, Vol. 58, No. 2, 277-297, 1991.

[5] M. Arellano, O. Bover. Another look at the instrumental variable estimation of error-components models", Journal of Econometrics, Vol. 68, 29-51, 1995.

[6] E. J. Arilyn. The effect of financial ratios and macroeconomic variables to financial distress of agriculture industry listed in the Indonesia Stock Exchange from 2013 to 2018, Advances in Economics, Business and Management Research, Vol. 115, 347-349, 2020.

[7] P. Asquith, R. Gertner, and D. Scharfstein. Anatomy of financial distress: an examination of junk-bond issuers, Quarterly Journal of Economics, Vol. 109, No. 3, 625-658, 1994

[8] N. Aydin, M. Basar, and M. Coskun. Financial Management. Ankara: Detay Publishing, 2010.

[9] R. Blundell, S. Bond. Initial conditions and moment restrictions in dynamic panel data models, Journal of Econometrics, Vol. 87, No. 1, 115-143, 1998.

[10] E. C. Charalambakis, I. Garrett. On corporate financial distress prediction: What can we learn from private firms in a developing economy? Evidence from Greece, Review of Quantitative Finance and Accounting, Vol. 52, 467-491,2019.

[11] A. Darmawan, J. Supriyanto. The effect of financial ratio on financial distress in predicting bankruptcy, Journal of Applied Managerial Accounting, Vol. 2, No. 1, 110-120, 2018.

[12] A. S. Ertan, O. Ersan. Determinants of financial default: the case of manufacturing industry in Turkey, Marmara University Journal of Economic and Administrative Sciences, Vol. 40, No. 2, 181-207, 2018.

[13] M. S. Jahur, S. M. N. Quadır, Financial Distress in Small and Medium Enterprises (SMES) of Bangladesh: Determinants and Remedial Measures, Economia Seria Management, Vol. 15, No. 1, 46-61, 2012.

[14] L. P. Hansen. Large sample properties of generalized method of moments estimators, Journal of the Econometric Society (Econometrica), Vol. 50, No. 4, 1029-1054, 1982.

[15] J. Hunter, N. Isachenkova. Failure risk: a comparative study of UK and Russian firms, Journal of Policy Modeling, Vol. 23, No. 5, 1-26, 2001.

[16] F. Ikpesu. Firm specific determinants of financial distress: empirical evidence from Nigeria, Journal of Accounting and Taxation, Vol. 11, No. 3, 49-56, 2019.

[17] D-K. Liou, M. Smith. Macroeconomic variables in the identification of financial distress, 2006, Available at SSRN: https://ssrn.com/abstract=900284 or http://dx.doi.or g/10.2139/ssrn.900284, 1-37.

[18] M. Maricica, V. Georgeta. Business failure risk analysis using financial ratios", Procedia Social and Behavioral 
Sciences, Vol. 62, 728-732, 2012.

[19] D. Martin. Early warning of bank failure: a logit regression approach, Journal of Banking and Finance, Vol. 1, No. 3, 249-276, 1977.

[20] R. McNamara, K. Duncan, and S. Kelly. Micro and macro determinants of financial distress, In T. Hoque (Ed.), Proceedings of the 15th International Business Research Conference, World Business Institute Australia, 1-25, 2011.

[21] A. Muslumov, M. Kayacan. The impact of economic variables on the return and risk of real sector: a case of SMEs in Turkey, SMEs in the 1st Century: Problems, Opportunities and Solution Proposals Symposium, 3-4 January, Gazimagusa: East Mediterranean University, 2002.

[22] D. Oktarina. Macroeconomic indicators and corporate financial ratios in predicting financial distress, The Indonesian Accounting Review, Vol.7, No. 2, 219-230, 2017.

[23] D. Olsson, A. Knutsson. Causes to financial distress in the Swedish construction industry: a quantitative study identifying the main causes to financial distress in the Swedish construction industry, Master Degree Project in Innovation and Industrial Management, University of Gothenburg, School of Business, Economics and Law, 42, 1-68, 2015.

[24] T. C. Opler, S. Titman. Financial distress and corporate performance, The Journal of Finance, Vol. 49, No. 3, 1015 1040, 1994.

[25] S. Ozcalik Guler, S. Aytekin. Determinants of Fulmer model: an evaluation of financial performance, International Journal of Economic and Administrative Studies, 17th Special Issue, 281-292, 2018.

[26] E. Pálinkó, A. Svoób. Main causes and process of financial distress an empirical analysis of Hungarian firms, Public Finance Quarterly, State Audit Office of Hungary, Vol. 61, No. 4, 516-532, 2016.

[27] H. D. Platt, M. B. Platt. Predicting corporate financial distress: reflections on choice-based sample bias, Journal of Economics and Finance, Vol. 26, No. 2, 184-199, 2002.

[28] A. Purnanandam. Financial distress and corporate risk management: theory and evidence, Journal of Financial Economics, Vol. 87, 706-739, 2008.

[29] D. Roodman. How to Do Xtabond2:An Introduction to Difference and System Gmm in Stata, Stata Journal, Vol. 9, No. 1, 86-136, 2009a.
[30] D. Roodman. A note on the theme of too many instruments, Oxford Bulletin of Economics and Statistics, Vol. 71, No. 1, 135-158, 2009b.

[31] E .G. Selassie, G. Tarekegn, and A. Ufo. Analysis of financial distress and its determinants in selected SMEs in Wolaita zone, Global Journal of Management and Business Research, Vol. 16, No. 8, 35-42, 2016

[32] G. L. V. Springate. Predicting the possibility of failure in a Canadian firm, Unpublished M.B.A. Research Project, Canada, Simon Fraser University, 1978.

[33] C. K. Thim, Y. V. Choong, and C. S. Nee. Factors affecting financial distress: the case of Malaysian public listed firms, Corporate Ownership and Control, Vol. 8, No. 4, 345-351, 2011.

[34] M. H. Tinoco, N Wilson. Financial distress and bankruptcy prediction among listed companies using accounting, market and macroeconomic variables, International Review of Financial Analysis, 2013, http://dx.doi.org/10.1016/j.irfa.2013.02.013, 1-26.

[35] M .A. Uddin, M. H. Ali, and M. Masih, M. Political stability and growth: an application of dynamic Gmm and quantile regression, Economic Modelling, Vol. 64, 610-625, 2017, doi:10.1016/j.econmod.2017.04.028

[36] R. C. West. A factor-analytic approach to bank condition, Journal of Banking and Finance, Vol. 9, No. 2, 253-266, 1985.

[37] R. B. Whitaker. The early stages of financial distress, Journal of Economics and Finance, Vol. 23, No. 2, 123-133, 1999.

[38] A. Yalcin, S. Gafuroglu. An empirical research to determine the managerial and functional effects of economic crises on small and medium-sized enterprises, Journal of Cukurova University Social Sciences Institute, Vol. 17, No. 2, 433448, 2008.

[39] F. Yang, Y. Bian. Analysis of financial status and determinants with Altman's z-score model: a panel data investigation from traditional Chinese medicine listed companies in China, Value in Health Journal, November, 22, S772, 2019.

[40] D. Yazdanfar, P. Öhman. Financial distress determinants among SMEs: empirical evidence from Sweden, Journal of Economic Studies, Vol. 47, No. 3, 547-560, 2019.

[41] E. M. Zelie, F. A. Wassie. Examining the financial distress condition and its determinant factors: a study on selected insurance companies in Ethiopia, World Journal of Education and Humanities, Vol. 1, No. 1, 64-75, 2019. 